\title{
SIZE DISTRIBUTION AND MATURITY OF THE SLIMEHEADS (Hoplostethus crassispinus) IN THE DEEP SEA AROUND SIMEULEU ISLAND, WESTERN SUMATERA, EASTERN INDIAN OCEAN
}

\author{
Badrudin"1), Ali Suman'2), and Awwaludin") \\ 1) Research Institute for Marine Fisheries, Muara Baru-Jakarta \\ 2) Research Center for Capture Fisheries, Ancol-Jakarta \\ Received December 22-2006; Received in revised February 5-2007; Accepted March 23-2007
}

\begin{abstract}
The slimeheads (Hoplostethus spp.) provide one of the likely economic important deep sea demersal fish resources in the near future. The fish was caught in western part of Sumatera, in the depth of more than 500 $m$ deep, and was found in substantial amount in the deep waters around Simeuleu Island and the western off Banda Aceh. Data analysis was limited to the biological aspects, including length relationship, and maturity. Total length relationships with both standard length and weight as well as condition factor $\left(\mathrm{K}=\left(\mathrm{W} / \mathrm{L}^{3}\right)^{*} 10^{2}\right)$ were explored. Identification of length of first maturity $(\mathrm{Lm})$ was also attempted. From the length distribution figure, it is likely that the slimeheads population consisted of one strong cohort. However, when it is separated, both the female, and male cohorts are likely consisted of two age groups. The female cohorts were represented by the length groups of approximately 31 and $39 \mathrm{~cm}$, while the male cohorts by the length groups of 33 and $38 \mathrm{~cm}$ length. It is found that the length of first maturity was $L m=31.9(32.0) \mathrm{cm}$. The total length (TL) and fork length (FL) relationship followed the equation of: $F L=0.821 \mathrm{TL}-5.0706$ ( $F L$ and $T L$ in $\mathrm{mm}$ ). The $\mathrm{LW}$ relationship followed the equation: $\mathrm{W}=0.0242 \mathrm{TL}^{2.9065}(\mathrm{~W}$ in grs, $\mathrm{TL}$ in $\mathrm{cm}$ ). Length and gonad weight $(\mathrm{Wg})$ relationship followed the power equation: $\mathrm{Wg}=0.000004 \mathrm{TL}^{4.1278}$ (Wg in $\mathrm{grs}$, $\mathrm{TL}$ in $\mathrm{mm}$ ), while the condition factors of the individual fish during this period ranging from 1.2 to 1.9. Exploitation of the slimeheads resources should consider the Lm factor. It suggest that the size of fish caught should be bigger than the size of Lm, so that the fish stock could hopefully be exploited sustainably.
\end{abstract}

KEYWORDS: $\quad$ size distribution, first maturity, length relationship, slimeheads, Western Sumatera, Eastern Indian Ocean

\section{INTRODUCTION}

The slimeheads (Hoplostethus spp.) provide one of the likely economic important deep sea demersal fish resources in the near future. The fish were caught in western part of Sumatera, in the depth of more than $500 \mathrm{~m}$ deep, and found in substantial amount in the waters around Simeuleu and the western of Banda Aceh (Anonymous, 2006). In the southern part of the Australian waters, the so called orange roughy (Hoplostethus atlanticus) provide the similar deep sea fish resources that have been commercially exploited (Anonymous, 1989; 1992), but until recently, in the waters of western Sumatera there has been no fishing activity targetting on the slimeheads resources. One of the differences between these two species is in their individual size where the orange roughy reaching to about $4.5 \mathrm{~kg}$, while the slimeheads during this survey was around $2.0 \mathrm{~kg}$. It seems that the average size of slimeheads in the western Sumatera was smaller than the orange roughy found in Australian waters. While the Australian orange roughy fishery provide the deep sea trawl fisheries where fishing activities carried out at 800 to $1500 \mathrm{~m}$ deep, the slimeheads in the waters of western Sumatera would likely provide the shallower fishery, as these resources were caught in substantial amount at the depth zone of 500 to $1,000 \mathrm{~m}$.

In relation with the environmental aspects such as the very huge pressure and scarcity of food supply, it is likely that the deep sea fishes having a very high sustainment for survive. In this aspect, the chemical substances of their flesh, such as proteins, lipids, and other biochemical substances will need further pharmacological laboratory research, analysis, and application. Preliminary results of analyses shows that the slimeheads, Hoplothethus crassispinus containing $23.4 \%$ proteins, $4.1 \%$ fats, $0 \%$ carbohydrates, $2.1 \%$ ashes, and $70.4 \%$ water (Suseno et al., 2007). It was also reported that 17 amino acids consisted of nine essential amino acids and eight non essential amino acids have been identified and high concentration of steroid components was found in the flesh of this species. It is likely that the slimeheads resources provide one of the inconventional fish resources that having prospect to be exploited in the near future. As it has been advised that exploitation of deep sea fish resources now days could hopefully be directed to get the benefit from the fish resources biodiversity and bioactive substances rather than catching fishes for direct human consumption (Badrudin et al., 2006). 
This paper describes some biological aspects of the slimeheads (Hoplostethus crassispinus) including length distributions, maturity, and its relationships. Determination of length af first maturity provides one of the important aspects in fisheries management. Information obtained could hopefully provide additional aspects that should be considered for the exploitation and management of the resources in the framework of gaining a continuing flow of products and income for an indefinite period. It is mandatory that any fish resources exploitation apply a certain measure that each individual fish caught has reached a certain size at which the fish has spawned at least once during their reproductive cycles. With this measure it is expected that the parental stocks can be maintained at a sufficient level to support their reproductive capacity. The size of parental stock usually varies in its significance as a determinant of future stock size.

\section{MATERIALS AND METHODS}

Data of this species were parts of the results of the demersal fish resources exploratory trawling using the $R / V$ Baruna Jaya IV, carried out in the framework of the Japan-Indonesia deep sea fisheries resources joint exploration marine research 2004, in the Western Sumatera of the Eastern Indian Ocean (Anonymous, 2006). Exploratory fishing covered the depth range of 250 to $1,000 \mathrm{~m}$, while data analysis in this paper was limited only to the biological aspects of the slimeheads (Hoplostethus crassispinus). These include the relationship between total and standard length, length and weight, and sexual maturity. Total length relationships with both standard length and weight as well as condition factor $\left(\mathrm{K}=\left(\mathrm{W} / \mathrm{L}^{3}\right)^{\star} 10^{2}\right)$ have been explored following the methods in biology of fish growth (lles, 1989; Weatherley \& Gill, 1987). Maturity stage of female fish were grouped into five points, of which the stage III, IV, and V were considered as mature. The description of each point of maturity following Isa et al. (2002) and are described in Table 3 (Appendix 2). Length of first maturity (Lm) was calculated following the procedures explained by Udupa (1986) as presented in Table 4 (Appendix 2). The stomach content analysis was only limited to the method of the frequency of occurence.

\section{RESULTS AND DISCUSSION}

\section{The Species}

Hoplostethus crassispinus belong to the family Trachichthydae. According to Nakabo (2002), this family consisted of three genera; Aulotrachichthys, Gephyroberix, and Hoplostethus. The pictorial keys to the species are: Dorsal with six spines and 13 fins; Anal with three spines and 9 to 10 fins; pectoral with 16 to 17 fins; and linea lateralis with 27 to 29 scales (D VI, 13; A III, 9 to 10; $P, 16$ to 17; LL 27 to 29). Munro (1955), described the morphology of the family as follows: Body fairly deep, moderately compressed. Head large, with thin surface bones bearing bony ridges bordering mucous canals. Fins with few spines but body rough. Other recorded species within the genus Hoplostethus in both references are $H$. crassispinus, $H$. rubellopterus, $H$. mediteranus, $H$. melanopus, $H$. Japonicus, and $H$. atlanticus. The first four species have been found in the deep waters of the Indian Ocean, the fifth in the waters of Japan while the sixth species has found and commercially exploited in the deep waters of the southeast Australia, which is well known as orange roughy.

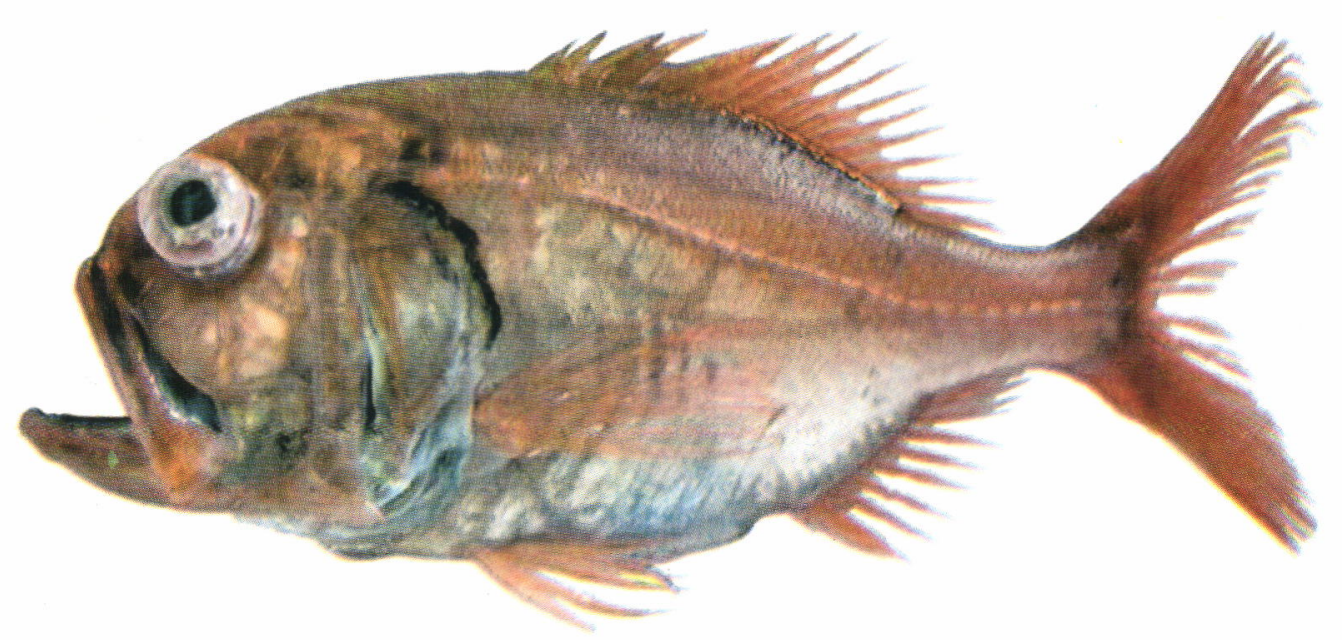

Figure 1. The slimeheads $(H$. crassispinus $) ;(L=38 \mathrm{~cm}, W=690 \mathrm{~g})$. 


\section{Length Distribution}

From a total of 102 fish sampled consisted of 57 female and 45 male, ranging from 18 to $47 \mathrm{~cm}$, it was found that the length distribution of total fish caught consisted of one strong mode (Figure 1, Table 1 and 2, Appendix 1). Differ with the shallow water demersal fish such as pony fish (Leiognathus splendens) reported by Badrudin (1987), silver biddy (Pentaprion longimanus)
(Badrudin \& Sudradjat, 1978), and goat fish (Upeneus sulphureus) (Beck \& Sudradjat, 1978) where the fish sampled consisted of several cohorts, it is likely that the deep sea fish of slimeheads sampled consisted of one strong cohort. However, when the length distribution is separated, both the female, and male cohorts are likely consisted of two age groups (Figure 2). The female cohorts were represented by the length groups of approximately 31 and $39 \mathrm{~cm}$, while the male cohorts by the length group of 33 and $38 \mathrm{~cm}$ length.

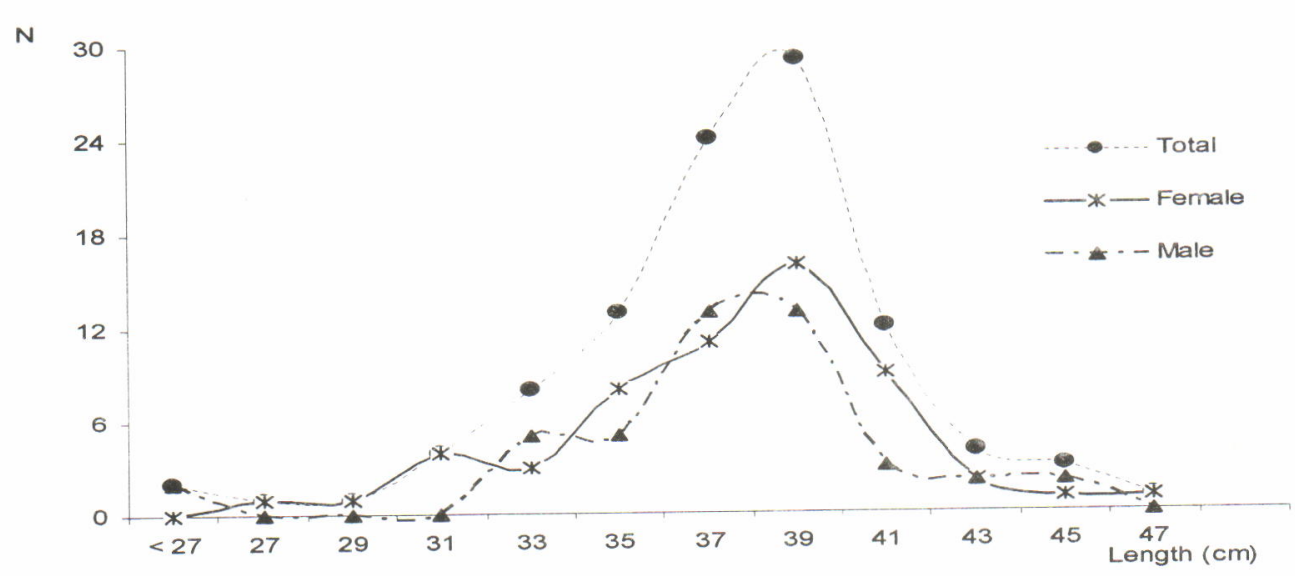

Figure 2. Length frequency distribution of the slimeheads ( $H$. crassispinus) sampled in the waters arru. Simeuleu, Western Sumatera, Eastern Indian Ocean.

\section{Length of First Maturity}

Length of first maturity (Lm) is defined as length group or class at which $50 \%$ of the fish in that group already mature. Identification of length of first maturity was only based on female slimeheads. From a number of 57 female fish sampled, 12 individuals fish were immature and 45 were mature.

Based on the L.m calculations (Table 4, Appendix 2), it is found that the length of first maturity of the slimeheads in the waters around Simeuleu was $L m=31.9$ $(32.0) \mathrm{cm}$, with $95 \%$ confidence limits of 30.1 to 33.7 $\mathrm{cm}$ total length. In connection with fishery management, exploitation of the slimeheads resources, Lm factor should hopefully be considered in determining the fishing method and technique to be applied. It is suggested that the size of fish caught would be bigger than the size of $\mathrm{Lm}$, so that to ensure the sustainability of the fish stock.

\section{Length Relationships}

Relationship between totai length and fork length, total length and weight as well as total length and gonad weight of the slimeheads $(H$. crassispinus) sampled in the waters around Simeuleu have been explored. With this relationship one can estimates any parameter in relation with the total length or vice versa. The total length $(T L-m m)$ and fork length (FL-mm) relationship of the slimeheads followed the equation of $F L=0.821 \mathrm{TL}$ $5.0706\left(R^{2}=0.954\right)$. The relationship forming a linear regression with a very high correlation coefficient. Length $(\mathrm{L})$ and weight $(\mathrm{W})$ relationship of most fish followed the power equation of $W=a L^{b}$. The $L W$ relationship of the slimeheads in the waters around Simeuleu followed the equation $W=0.0242 \mathrm{TL}^{2.9065}\left(R^{2}=0.893\right)$, where $W$ in $\mathrm{g}$ and $T L$ in $\mathrm{cm}$. It is likely that the growth pattern of this fish was almost isometric, where boo 3 . As in the LW relationship, the length and gonad weight $(\mathrm{Wg})$ relationship also followed the power equation $W g=0.000004 T L^{4.1278}\left(R^{2}=0.748\right)$, where $W$ in $g$ and $T L$ in $\mathrm{mm}$. 


\section{Condition Factor}

The condition factor $(\mathrm{K})$ of the fish ranging from 1.2 to 1.9 (Tabel 5, Appendix 3). Condition is described as a morphometric interpretation of a fish's plumpness as compared to the population mean. Condition is a useful measure of assessing the physiological state of a fish. The mass of all major body constituent with the exception for the inorganic compounds, must decrease with a decline in condition. The equation of condition factor emphasizes the fact that the total condition factor of an individual fish can be affected by any independent changes that may occur in individual component. Conversely, any change in the total condition factor cannot be interpreted as a change in any single component unless those in other component can also be accounted for.

According to Weatherley \& Gill (1987), the procedure of $K$ determination has been utilized effectively in three kind of population analysis. The first, in comparing two or more conspecific populations living either under similar, or different, conditions of food, density, climate etc. The second, in determining the timing and duration of gonad maturation, and the third in following the gradual build up or decline of feeding activity over an extended period, or of population changes possibly attributable to alterations in the food supply, condition change may be found to reflect fairly faithfully the change in body protein content and (especially) lipid content that occur.

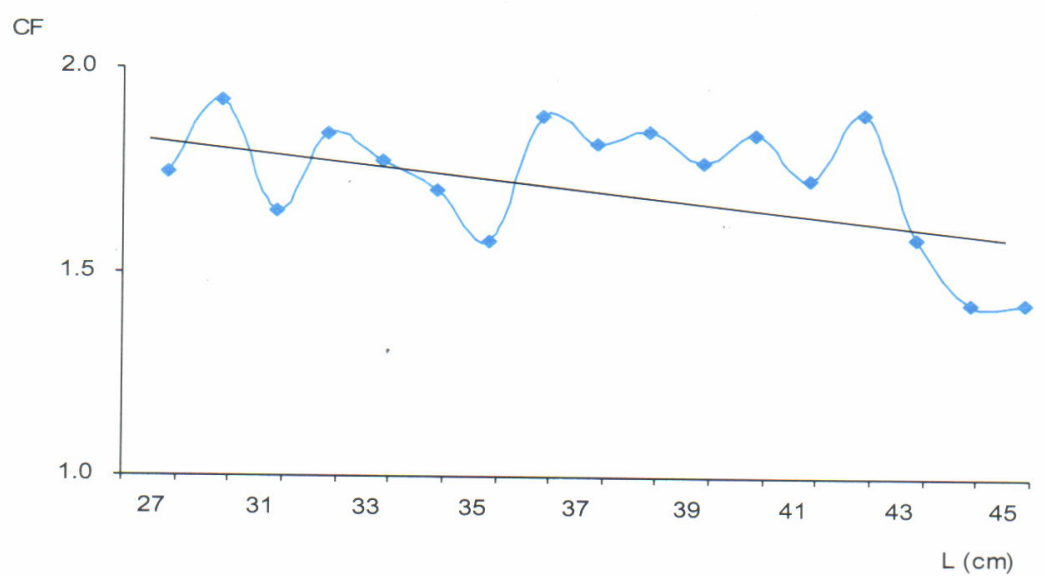

Figure 3. Plot of condition factor (CF) againts total length (TL) of slimeheads ( $H$. crassispinus ) sampled in the waters around Simeuleu, Western Sumatera, Eastern Indian Ocean.

It is likely that the trend of condition factor (Figure 3) is decreasing toward the bigger size of the fish. This was consistent with Caulton (1982), that the mass of all major body constituent with the exception for the inorganic compounds, must decrease with a decline in condition. In connection with the $L m=32 \mathrm{~cm}$, it is clear that this size is correspond to the second peak of the $\mathrm{CF}$ graph. With this situation, catching fish at this point $($ size $>32 \mathrm{~cm})$ will give opportunity for fish to spawn at least once or twice prior to be finally fished or caught.

\section{Stomach Content}

From a stomach content analysis it is possible to identify an inter ecological relationships between the fish itself and organisms found in their stomach. By using the frequency of occurrence it was found that the food habit of the slimeheads mainly consisted of other fish, shrimp, and worms. The percentage of these food items were paralepididae $12.2 \%$, benthodesmus $2.7 \%$, unidentified fish $27 \%$, shrimp $20.3 \%$, worms $35.1 \%$, and squids $2.7 \%$. From these figure it is likely that the slimeheads provide a demersal predator fish.

\section{CONCLUSION}

The slimeheads (Hoplostethus spp.) provide one of the likely economic important deep sea fish resources found in substantial amount in the deep waters around Simeuleu Island to the western of Banda Aceh. Both the female and male cohorts of the slimeheads population consisted of two age groups. The female cohorts were represented by the length groups of approximately 31 and $39 \mathrm{~cm}$, while the male cohorts by the length groups of 33 and $38 \mathrm{~cm}$ length. The condition factor of the fish ranging from 1.2 to 1.9. It was found that the length of first maturity was $L \mathrm{Lm}=31.9(32.0) \mathrm{cm}$. It is suggested that the size of fish caught should be bigger than the size of Lm, so that the fish stock could hopefully be exploited sustainably. 


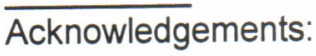

This paper is part of 'Indonesian-Japan joint program on deep sea fisheries resources' in 2005.

\section{REFERENCES}

Anonymous. 2006. The Japan-Indonesia deep sea fishery resources joint exploration project. Project Report. OFCF-RIMF. $151 \mathrm{p}$.

Anonymous. 1992. Background fisheries statistics. DPIE. Canberra. Australia. August 1992. Issue No.6. $47 \mathrm{p}$.

Anonymous. 1989. New directions for commonwealth fisheries management in the 1990s. Australian Government Publishing Service. Canberra. $114 \mathrm{p}$.

Badrudin. 1987. The recovery of demersal fish stock and the stock parameters of the splendid pony fish, Leiognathus splendens, in the north coast of Central Java. Indonesia. M. S. thesis. School of Animal Biology.Univ. Coll. of North Wales. Bangor. UK. 57 p.

Badrudin \& A. Sudradjat. 1978. Age, growth, and some biological aspects of silver biddy (Pentaprion longimanus, Cantor) in the Java Sea. Marine Fisheries Resources. Report. No.1/78 PL-081/78: 6378. (In Indonesian with English Abstract).

Badrudin, Wudianto, N. N. Wiadnyana, \& S. Nurhakim. 2006. Deep sea fish resources potential and diversity in the waters of western Sumatera of the eastern Indian Ocean. Indonesian Fisheries Resources Journal. AMFR. Vol.12. No.1 (2006).

Beck, U. \& A. Sudradjat, 1978. Variation in size and composition of demersal trawl catches from the north coast of Java with estimated growth parameters for three important food fish species. Marine Fisheries Resources Report Contribution of the Dem. Fisheries Project No.4. Jakarta. 80 p.

Caulton, M. S. 1982. Feeding metabolism and growth of tilapias: Some quantitative considerations. Pp. 157-180. In R. S. V. Pullin \& R. H. Lowe Mc Connel (Eds). The biology and culture of tilapia. ICLARM Conference Procidding. 7. 432 p. ICLARM. Manila.

Iles, T. D. 1989. Allocation of resources to gonad and soma in Atlantic herring Clupea harengus L. In Potts G. W. \& R. J. Wootton (Eds). Fish Reproduction: Strategies and tactics. Academic Press. London. Pp: 331-348.

Isa M. M., R. Rumpet, S. A. S. A. Kadir, S. Ishikawa, \& S. Siriraksophon. 2002. Standard operating procedures for pilot data collection and analysis. Marine Fisheries Resources Dev. and Management Department SEAFDEC. 22 p.

Munro, I. S. R. 1955. The marine and fresh water fish of Ceylon. Min. of External Affairs. Canberra. xvi+351 p. 56 plates.

Nakabo, T. 2002. Fishes of Japan with pictorial keys to the species. Tokai University Press. Book I: 866 p. Book II: 867-1748.

Suseno, S. H., A. Suman, Wudianto, \& A. Damayanti. 2007 (This volume). Nutrient and steroid contents of some deep sea fish from the waters of western Sumatera, Eastern Indian Ocean. Indonesian Fisheries Resources Journal. AMFR. Vol. ... No. ..

Udupa, K. S. 1986. Statistical method of estimating the size of first maturity in fish. Fishbyte. Vol.4 No.2 August 1986: 8-10.

Weatherley, A. H. \& H. S. Gill. 1987. The biology of fish growth. Academic Press. London. $443 p$. 
Appendix 1.

Table 1. Length frequency distribution of male and female of the slimeheads (Hoplostethus crassispinus)

\begin{tabular}{ccccc}
\hline Length group & Mid length & No.sample & Female & Male \\
\hline$<26$ & $<27$ & 2 & & 2 \\
$26-28$ & 27 & 1 & 1 & - \\
$28-30$ & 29 & 1 & 1 & - \\
$30-32$ & 31 & 4 & 4 & - \\
$32-34$ & 33 & 8 & 3 & 5 \\
$34-36$ & 35 & 13 & 8 & 5 \\
$36-38$ & 37 & 24 & 11 & 13 \\
$38-40$ & 39 & 29 & 16 & 13 \\
$40-42$ & 41 & 12 & 9 & 3 \\
$42-44$ & 43 & 4 & 2 & 2 \\
$44-46$ & 45 & 3 & 1 & 2 \\
$46-48$ & 47 & 1 & 1 & \\
\hline
\end{tabular}

Table 2. Number of mature and immature female slimeheads ( $H$. crassispinus ) sampled in the waters around Simeule, Western Sumatera, Eastern Indian Ocean

\begin{tabular}{ccccc}
\hline Length group & Mid Length & No.sample & Immature & Fully mature \\
\hline $26-28$ & 27 & 1 & 1 & - \\
$28-30$ & 29 & 1 & 1 & - \\
$30-32$ & 31 & 4 & 3 & 1 \\
$32-34$ & 33 & 3 & 2 & 1 \\
$34-36$ & 35 & 8 & 5 & 3 \\
$36-38$ & 37 & 11 & - & 11 \\
$38-40$ & 39 & 16 & - & 16 \\
$40-42$ & 41 & 9 & - & 9 \\
$42-44$ & 43 & 2 & - & 2 \\
$44-46$ & 45 & 1 & - & 1 \\
$46-48$ & 47 & 1 & - & 1 \\
\hline \multicolumn{7}{c}{ Total } & & $\mathbf{5 7}$ & $\mathbf{1 2}$ & $\mathbf{4 5}$ \\
\hline
\end{tabular}


Appendix 2.

Table 3. $\quad$ Five point maturity scale for partial spawners (Isa et al., 2002)

\begin{tabular}{|c|c|c|}
\hline Stage & State & Description \\
\hline $\mathrm{I}$ & Immature & $\begin{array}{l}\text { Ovary and testis about } 1 / 3 \text { length of body cavity. Ovaries pinkish, translucent; testis } \\
\text { whitish. Ova not visible to naked eye. }\end{array}$ \\
\hline II & Maturing & $\begin{array}{l}\text { Ovary and testis about } 1 / 2 \text { length of body cavity. Ovary pinkish, translucent; testis } \\
\text { whitish, more, or less symmetrical. Ova not visible to naked eye. }\end{array}$ \\
\hline III & Ripening & $\begin{array}{l}\text { Ovary and testis is about } 2 / 3 \text { length of body cavity. Ovary pinkish yellow colour with } \\
\text { granular appearance, testis whitish to creamy. No transparent or translucent ova } \\
\text { visible. }\end{array}$ \\
\hline IV & Ripe & $\begin{array}{l}\text { Ovary and testis from } 2 / 3 \text { to full length of body cavity. Ovary orange pink in colour with } \\
\text { conspicuous superficial blood vessels. Large transparent, ripe ova visible. Testis } \\
\text { whitish creamy soft. }\end{array}$ \\
\hline V & Spent & $\begin{array}{l}\text { Ovary and testis shrunken to about } 1 / 2 \text { length of body cavity. Walls loose. Ovary may } \\
\text { contain remnants of disintegrating opaque and ripe ova, darkened, or translucent. } \\
\text { Testis blood shot and flabby. }\end{array}$ \\
\hline
\end{tabular}

Table 4.

Calculation procedures for the estimation of length at first maturity ( $\mathrm{Lm}$ ) of slimeheads, Hoplostethus crassispinus (Udupa, 1986)

\begin{tabular}{|c|c|c|c|c|c|c|c|c|c|}
\hline \multirow[t]{2}{*}{$\begin{array}{l}\text { Length } \\
\text { group }\end{array}$} & \multirow[t]{2}{*}{$\begin{array}{l}\text { Mid } \\
\text { length }\end{array}$} & $\begin{array}{l}\text { Log } \\
\text { mid length }\end{array}$ & $\begin{array}{l}\text { No. } \\
\text { sample }\end{array}$ & \multirow[t]{2}{*}{ Immature } & \multirow[t]{2}{*}{$\begin{array}{l}\text { Fully } \\
\text { mature }\end{array}$} & $\begin{array}{l}\% \text { fully } \\
\text { mature }\end{array}$ & $X i+1-X i=X$ & \multirow[t]{2}{*}{$q i=1-p i$} & \multirow[t]{2}{*}{ pi.qi/ni-1 } \\
\hline & & $(\mathrm{Xi})$ & (ni) & & & (ri) & (pi) & & \\
\hline $26-28$ & 27 & 1.4314 & 1 & 1 & & & & & \\
\hline $28-30$ & 29 & 1.4624 & 1 & 1 & & & 0.0310 & & \\
\hline $30-32$ & 31 & 1.4914 & 4 & 3 & 1 & 0.250 & 0.0290 & 0.750 & 0.0625 \\
\hline $32-34$ & 33 & 1.5185 & 3 & 2 & 1 & 0.330 & 0.0272 & 0.670 & 0.0737 \\
\hline $34-36$ & 35 & 1.5441 & 8 & 5 & 3 & 0.375 & 0.0256 & 0.625 & 0.0335 \\
\hline $36-38$ & 37 & $\left.1.5682^{\circ}\right)$ & 11 & & 11 & 1.000 & 0.0241 & & \\
\hline $38-40$ & 39 & 1.5911 & 16 & & 16 & & & & \\
\hline $40-42$ & 41 & 1.6128 & 9 & & 9 & & & & \\
\hline $42-44$ & 43 & 1.6335 & 2 & & 2 & & & & \\
\hline $44-46$ & 45 & 1.6532 & 1 & & 1 & & & & \\
\hline \multirow[t]{2}{*}{$46-48$} & 47 & 1.6721 & 1 & & 1 & & & & \\
\hline & & & 57 & 12 & 45 & 1.955 & 0.03 & & 0.1697 \\
\hline
\end{tabular}

Remarks: " Last log size at which $100 \%$ fully mature $m=1.5682+(0.03 / 2)-(0.03 * 1.955)$

$\mathrm{m}=1.5034$

Antilog $(1.5034)=31.87 \mathrm{~cm} \rightarrow \mathrm{Lm}=31.9 \mathrm{~cm}$

95\% Confidence limits

Upper limit: Antilog $\left(1.5034+1.96 "\left(0.03^{2 *} 0.1697\right)=33.7\right.$

Lower limit: Antilog (1.5034-1.96 “ $\left(0.03^{2 *} 0.1697\right)=30.1$

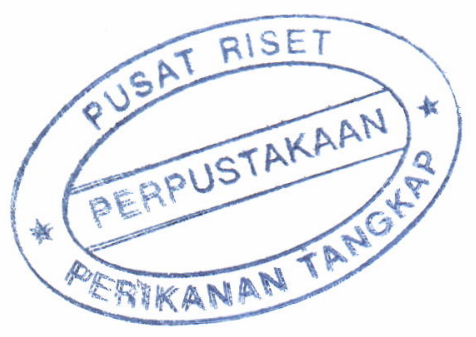


Appendix 3.

Table 5. Calculated condition factor for each length of individual fish and its mean

\begin{tabular}{|c|c|c|c|c|c|}
\hline$L(\mathrm{~cm})$ & CF & $\mathrm{L}(\mathrm{cm})$ & CF & $\mathrm{L}(\mathrm{cm})$ & CF \\
\hline 18 & 1.715 & 36 & 1.758 & 39 & 1.575 \\
\hline 18 & 1.742 & 36 & 1.747 & 39 & 1.829 \\
\hline \multirow[t]{2}{*}{ Mean } & 1.73 & 36 & 1.507 & 39 & 1.758 \\
\hline & & 36 & 2.068 & 39 & 1.905 \\
\hline \multirow[t]{2}{*}{27} & 1.73 & 36 & 2.025 & 39 & 1.956 \\
\hline & & 36 & 1.865 & 39 & 1.618 \\
\hline 30 & 1.581 & 36 & 1.960 & 39 & 1.694 \\
\hline 30 & 2.438 & 36 & 2.139 & 39 & 1.585 \\
\hline 30 & 1.685 & 36 & 1.629 & 39 & 1.875 \\
\hline \multirow[t]{2}{*}{ Mean } & 1.901 & Mean & 1.86 & 39 & 1.585 \\
\hline & & & & 39 & 1.551 \\
\hline 31 & 1.544 & 37 & 1.797 & 39 & 1.888 \\
\hline 31 & 1.711 & 37 & 1.678 & 39 & 1.913 \\
\hline \multirow[t]{2}{*}{ Mean } & 1.628 & 37 & 1.945 & 39 & 1.644 \\
\hline & & 37 & 1.589 & Mean & 1.74 \\
\hline 32 & 1.801 & 37 & 1.885 & & \\
\hline 32 & 1.846 & 37 & 1.964 & 40 & 1.719 \\
\hline \multirow[t]{2}{*}{ Mean } & 1.82 & 37 & 1.767 & 40 & 1.786 \\
\hline & & 37 & 1.912 & 40 & 1.737 \\
\hline 33 & 1.763 & 37 & 1.873 & 40 & 1.961 \\
\hline 33 & 1.864 & 37 & 1.826 & 40 & 1.786 \\
\hline 33 & 1.686 & 37 & 1.885 & 40 & 1.634 \\
\hline 33 & 1.664 & 37 & 1.441 & 40 & 1.883 \\
\hline 33 & 1.795 & 37 & 1.895 & 40 & 2.001 \\
\hline \multirow[t]{2}{*}{ Mean } & 1.75 & 37 & 1.579 & 40 & 1.881 \\
\hline & & 37 & 1.846 & 40 & 1.688 \\
\hline 34 & 1.438 & Mean & 1.79 & Mean & 1.81 \\
\hline 34 & 1.593 & & & & \\
\hline 34 & 1.845 & 38 & 2.123 & 41 & 1.763 \\
\hline 34 & 1.641 & 38 & 2.114 & 41 & 1.553 \\
\hline 34 & 1.908 & 38 & 1.859 & 41 & 1.821 \\
\hline \multirow[t]{2}{*}{ Mean } & 1.68 & 38 & 1.659 & 41 & 1.654 \\
\hline & & 38 & 1.863 & Mean & 1.70 \\
\hline 35 & 1.563 & 38 & 1.841 & & \\
\hline 35 & 1.563 & 38 & 1.658 & 42 & 1.667 \\
\hline 35 & 1.749 & 38 & 1.904 & 42 & 1.795 \\
\hline 35 & 1.726 & 38 & 1.658 & 42 & 2.119 \\
\hline 35 & 1.294 & 38 & 1.813 & Mean & 1.86 \\
\hline 35 & 1.889 & 38 & 1.555 & & \\
\hline 35 & 1.120 & 38 & 1.750 & 43 & 1.55 \\
\hline 35 & 1.458 & 38 & 1.832 & & \\
\hline \multirow[t]{2}{*}{ Mean } & 1.55 & 38 & 1.857 & 44 & 0.998 \\
\hline & & Mean & 1.82 & 44 & 1.779 \\
\hline 46 & 1.39 & & & Mean & 1.39 \\
\hline
\end{tabular}

